\title{
RENCANA TATA BANGUNAN DAN LINGKUNGAN (RTBL) DALAM MENATA RUANG KOTA
}

\author{
Ilva Nurfitriati \\ email: ilva.effendi@yahoo.com
}

\begin{abstract}
Urban society has a placed a considerable amount of hope in and holds great expectations of the Urban Planning Program (RTRWK) on RTRWK as the solution to urban planning problems. This program serves as a general guideline for urban planning, although much more detailed regulations are certainly required. The Building and Developmental Planning Program (RTBL) contains urban planning regulations that are in fact already in place despite its being much less popular and/or well known compared to its counterparts: RTRWK or even RDTR (Detailed Urban Space Management Program). Urban and environmental development planning can be one of the solutions for urban management and regulations in accordance with Law No. 26 of 2007 concerning Urban Planning, as well as government regulations for urban planning management. In this study, attempts are made to describe and explain how RTBL can be utilized as a so-called tandem solution to certain urban planning problems, after taking into consideration that various urban areas have distinct characteristics and priorities.
\end{abstract}

Keywords:

RTRW, RTBL, Spatial Planning, Urban Area Management, Urban Planning

\begin{abstract}
Abstrak
Masyarakat Kota menaruh harapan pada Rencana Tata Ruang Wilayah Kota (RTRWK) untuk dapat menjadi solusi dari permasalahan penataan ruang. RTRWK berfungsi sebagai pedoman umum dalam menata kota, sedangkan diperlukan peraturan pelaksana yang mengatur lebih rinci. Rencana Tata Bangunan dan Lingkungan (RTBL) merupakan salah satu peraturan pelaksana dari penataan ruang. Hanya saja RTBL belum sepopuler RTRW ataupun Rencana Detail Tata Ruang (RDTR). Rencana Tata Bangunan dan Lingkungan dapat menjadi salah satu solusi pengaturan tata ruang berdasarkan amanat Undang-Undang Nomor 26 Tahun 2007 tentang Penataan Ruang dan Peraturan Pemerintah tentang Penyelenggaraan Penataan Ruang. Penulis mencoba memaparkan bagaimana RTBL dapat menjadi solusi pendamping permasalahan tata ruang mengingat beberapa bagian wilayah kota memiliki karakter dan prioritas yang berbeda.
\end{abstract}

Kata Kunci:

RTRW, RTBL, Penataan Ruang, Pengaturan ruang kota, Tata kota

\section{Pendahuluan}

Jumlah penduduk di perkotaan menunjukkan kecenderungan pertumbuhan yang semakin meningkat dan cepat. Menjadi sesuatu yang wajar karena daerah perkotaan mempunyai daya tarik yang kuat ${ }^{1}$. Jumlah penduduk

1 Juniarso Ridwan dan Achmad Sodik, Hukum Tata Ruang Dalam Konsep Kebijakan Otonomi Daerah 137 (Nuansa Bandung, 2013). 
perkotaan yang relatif padat tersebut membutuhkan ketersediaan prasarana dan sarana perkotaan dan berbagai fasilitas pelayanan ekonomi juga sosial dalam jumlah yang cukup besar serta kualitas pelayanan umum yang cukup memadai ${ }^{2}$. Permintaan pelayanan prasarana dan sarana yang dibutuhkan di daerah perkotaan pada umumnya dirasakan jauh lebih besar dibandingkan dengan ketersediaan prasarana dan sarana yang dibangun ${ }^{3}$. Tidak seimbangnya prasarana dan sarana perkotaan dibanding dengan pertumbuhan penduduk menimbulkan ketidakteraturan ${ }^{4}$.

Di sisi lain, keteraturan, bahkan kerapihan dan keindahan tata kota (ataupun kabupaten ${ }^{5}$ ) seringkali menjadi opini/pernyataan awal ketika singgah di sebuah kota. Penilaian akan kinerja terhadap pemerintah yang sedang berjalan secara subjektif akan dipengaruhi oleh tampilan tata kotanya. Bagaimana pemerintah mengatur, mengelola, mengawasi hingga tegas dalam menerapkan sanksi ketika ketidakteraturan kota terjadi. Masyarakat secara pedas seringkali mengkritisi kinerja pemerintah terkait pengaturan dari sebuah kota. Menurut Aristoteles, kota adalah "politik yang dibangun": di sana terdapat interaksi yang kuat antara bentuk dan nilai-nilai politiknya yang mendominasi penyelenggaraannya. Sedangkan, Vitruvius menyelipkan unsur estetika pada sebuah kota, karena ia menginginkan agar kota menjadi solid, indah, dan berguna $^{6}$. Jika politik yang dibangun berlangsung mulus, dilengkapi dengan terbentuknya kota yang solid, indah dan berguna, sepertinya dapat tercipta sebuah kota ideal.

2 Id.

3 Id., hlm., 138.

4 Id., hlm., 142.

5 Untuk selanjutnya penyebutan kata kota akan diasumsikan bersamaan dengan penyebutan kabupaten.

6 Voula Mega, Konsep dan Peradaban Masyarakat Berwawasan Ekologi: Dilema, Inovasi, dan Drama Perkotaan 48. 
Berkaitan dengan semakin populernya isu Rencana Tata Ruang Wilayah $\left(\mathrm{RTRW}^{7}\right)$ dan terbukanya masyarakat dengan isu tata ruang, penulis beranggapan, saat ini merupakan waktu yang tepat untuk lebih memperkenalkan atau mengingatkan adanya perangkat Rencana Tata Bangunan dan Lingkungan $\left(\mathrm{RTBL}^{8}\right)$ sebagai salah satu solusi penataan ruang yang merupakan bagian dari peraturan penataan ruang. Penulis melihat, kurangnya beberapa ketersediaan sarana dan prasarana ${ }^{9}$ pada ruang seperti yang diinginkan oleh masyarakat, mungkin saja memang tidak diakomodasi oleh RTRW, namun harus disediakan oleh peraturan pelaksana yang diamanatkan oleh peraturan yang lebih tinggi. Dalam hal ini bisa saja harus diatur pada RTBL.

Keragaman yang berpengaruh terhadap pembentukan sebuah kota, pada akhirnya akan mempengaruhi tata cara mengatur kota itu sendiri. Dalam hal ini penulis melihat, bergantung pada RTRW saja tidak cukup dalam mengakomodasi kebutuhan masyarakat kota, RTRW sebagai perangkat pengatur yang berlaku secara umum, memerlukan peraturan pelaksana yang dapat menguraikan lebih rinci kebutuhan warga kota yang beragam. Kota (Bandung) dalam mengimplementasikan rencana tata ruangnya, telah mengamanatkan untuk disusunnya peraturan tata ruang dalam bentuk Rencana Tata Bangunan dan Lingkungan (RTBL). Sebagai contoh, Kota Bandung melalui Peraturan Daerah Kota Bandung Nomor 18 Tahun 2011 tentang Rencana Tata Ruang Wilayah (RTRW) Kota Bandung 2011-2031, mengamanatkan ${ }^{10}$ untuk membentuk RTBL pada wilayah/kawasan tertentu.

\footnotetext{
${ }^{7}$ Untuk selanjutnya akan disingkat dengan RTRW.

${ }^{8}$ Untuk selanjutnya akan disingkat dengan RTBL.

9 Peraturan Menteri Pekerjaan Umum, Nomor 6 Tahun 2007, Pedoman Penyusunan Rencana Tata Bangunan dan Lingkungan, Lampiran Bagian II Umum. Program bangunan dan lingkungan merupakan penjabaran lebih lanjut dari perencanaan dan peruntukan lahan yang telah ditetapkan untuk kurun waktu tertentu, yang memuat jenis, jumlah, besaran, dan luasan bangunan gedung, serta kebutuhan ruang terbuka hijau, fasilitas umum, fasilitas sosial, prasarana aksesibilitas, sarana pencahayaan, dan sarana penyehatan lingkungan, baik berupa penataan prasarana dan sarana yang sudah ada maupun baru.

${ }^{10}$ Dapat dilihat pada bagian mengenal RTBL artikel ini.
} 
Dari apa yang telah dipaparkan oleh penulis, tulisan ini bertujuan untuk mencari jawaban atas permasalahan tata ruang yang terjadi melalui salah satu perangkat tata ruang yang dimiliki oleh perundang-undangan. Permasalahan yang diangkat diidentifikasikan sebagai berikut: Melalui Rencana Tata Ruang Wilayah Nasional (RTRW Nasional) diamanatkan bahwa bagi daerah tingkat Provinsi, Kabupaten dan Kota agar menyusun rencana tata ruang dan wilayah sesuai dengan kebutuhan dan kemampuan masing-masing daerah. Setiap perencanaan tata ruang wilayah diasumsikan telah mempertimbangkan dinamika pembangunan skala jangka pendek hingga jangka panjang. Namun, mengapa pada pelaksanaannya masih terjadi pembangunan yang tidak sesuai dengan peruntukkannya serta beragam permasalahan penataan ruang meskipun wilayah tersebut telah memiliki RTRW? Peraturan tata ruang memiliki perangkatperangkat dalam menata ruang, selain RTRW, terdapat perangkat RTBL, karenanya tulisan ini juga hendak melihat, apakah RTBL sebagai salah satu instrumen pelaksana penataan ruang dapat menjadi solusi atas permasalahan yang disebutkan sebelumnya.

\section{Penataan Ruang dan Rencana Tata Ruang}

Saat ini masyarakat berasumsi jika RTRW merupakan indikator keberhasilan pemerintah dalam menata ruang, tak jarang masyarakat pun berasumsi jika kesemerawutan kota adalah buah dari RTRW yang tidak sesuai dengan kota yang diaturnya. Masyarakat kadangkala menuntut RTRW dapat menjawab seluruh permasalahan tata ruang kota, di lain pihak, apa yang terdapat pada RTRW adalah panduan umum. Diperlukan peraturan pelaksana bagi tiap kawasan atau wilayah pada sebuah kota. Salah satunya adalah dengan pembentukan RTBL.

Ketika pertumbuhan penduduk di suatu wilayah cukup pesat, masyarakatnya seringkali menuntut pemerintah untuk mampu menyediakan berbagai sarana dan prasarana pemenuhan hidup bagi rakyat. Pemenuhan 
kebutuhan untuk mencukupi masyarakat dikatakan sebagai salah satu kewajiban pemerintah dalam sebuah Negara yang menganut paham "welfare state". Negara dituntut untuk berperan lebih jauh dan melakukan campur tangan terhadap aspek-aspek pemenuhan kebutuhan masyarakat dalam rangka mewujudkan kesejahteraan rakyatnya .

Alfitri ${ }^{11}$ menjelaskan pada tulisannya, para pendiri negara Indonesia telah menyepakati bahwa salah satu tujuan didirikannya negara Indonesia adalah agar keadilan dan kemakmuran bangsa Indonesia bisa diwujudkan. Unsur-unsur welfare state ini telah dimasukkan ke dalam dasar negara Indonesia (Pancasila dan Undang-Undang Dasar 1945) pada saat persiapan rapat pembahasan persiapan dan paska kemerdekaan negara Indonesia. Pembukaan Undang-Undang Dasar 1945 yang memuat rumusan tujuan negara Indonesia dan juga Pancasila menyatakan bahwa negara Indonesia dibentuk, “... untuk melindungi segenap bangsa Indonesia dan seluruh tumpah darah Indonesia dan untuk memajukan kesejahteraan umum, mencerdaskan kehidupan bangsa, dan ikut melaksanakan ketertiban dunia ... dengan berdasar kepada [disini kemudian teks Pancasila muncul] ... keadilan sosial bagi seluruh rakyat Indonesia."12. Rumusan dasar ideologi welfare state tersebut ("memajukan kesejahteraan umum" dan sila kelima Pancasila "keadilan sosial bagi seluruh rakyat Indonesia") kemudian dimanifestasikan ke dalam batang tubuh konstitusi negara Indonesia untuk dijadikan pedoman hidup berbangsa dan penyelenggaraan kenegaraan.

Dasar Negara Indonesia tersebut menjadi landasan bahwa pemerintah wajib menyediakan apa yang dibutuhkan oleh warganya. Dalam hal ini, ketertiban yang merupakan tujuan dari penataan ruang merupakan kebutuhan dari

11 Alfitri, Ideologi Welfare State dalam Dasar Negara Indonesia. Volume 9 Nomor 3 Jurnal Konstitusi. 458. (September 2012).

12 Pembukaan Undang-Undang Dasar 1945. 
masyarakat kota dan untuk kepentingan tersebut, pemerintah berkewajiban menjamin ketertiban yang dibutuhkan oleh masyarakat.

Undang-undang Nomor 26 Tahun 2007 tentang Penataan Ruang juga menjamin bahwa penataan ruang bertujuan untuk menjamin kepastian hukum dan terciptanya keadilan, pemerintah sebagai aparat Negara merupakan perangkat yang diberikan kewajiban untuk menjamin terwujudnya tujuan tersebut. Pencapaian ini diatur pada asas kepastian hukum dan keadilan. Penjelasan Pasal 2, huruf f, Undang-Undang Penataan Ruang:

"Asas kepastian hukum dan keadilan, maksudnya penataan ruang diselenggarakan dengan berlandaskan hukum/ketentuan peraturan perundang-undangan dan bahwa penataan ruang dilaksanakan dengan mempertimbangkan rasa keadilan masyarakat serta melindungi hak dan kewajiban semua pihak secara adil dengan jaminan kepastian hukum".

Undang-undang Penataan Ruang menjamin juga tercapainya keteraturan berdasarkan asas keserasian, keselarasan dan keseimbangan yang tercantum pada Penjelasan Pasal 2, huruf b, Undang-Undang Penataan Ruang:

"Asas keserasian, keselarasan, dan keseimbangan, maksudnya penataan ruang diselenggarakan dengan mewujudkan keserasian antara struktur ruang dan pola ruang, keselarasan antara kehidupan manusia dan lingkungannya, keseimbangan pertumbuhan dan perkembangan antar daerah serta antar kawasan perkotaan dan kawasan perdesaan".

RTRW diasumsikan menjadi buku sakral yang diharapkan memuat seluruh rincian ketentuan pengaturan tata ruang, diharapkan untuk dapat menjawab dan menyelesaikan setiap pertanyaan dan permasalahan yang menyangkut penataan ruang pada sebuah kota. Sebagai contoh, Peraturan Daerah Kota Bandung Nomor 18 Tahun 2011 tentang RTRW Kota Bandung 2011 - 2031. Pengaturan Kota Bandung mengacu pada Peraturan Daerah Nomor 18 Tahun 2011, terdapat beberapa rincian teknis yang belum dimuat pada Peraturan Daerah Nomor 18 
Tahun 2011, terhadap hal ini, masyarakat seringkali menumpukan kritik bahwa Peraturan Daerah Nomor 18 Tahun 2011 Tentang RTRW Kota Bandung tidak disusun secara menyeluruh.

Pada Buku Rencana Tata Ruang Wilayah Kota Bandung Nomor 18 Tahun 2011, Bab 2 mengenai tujuan, kebijakan dan strategis, telah dijelaskan,

"bahwasanya berdasarkan Pengendalian pemanfaatan ruang mengacu kepada RTRWK, atau rencana yang lebih rinci (RDTRK) dan Peraturan Zonasi (PZ) yang berlaku, dengan memperhatikan ketentuan, standar teknis, kelengkapan prasarana, kualitas ruang, dan standar kinerja kegiatan yang ditetapkan".

Disebutkan pula, bahwa strategi yang akan diterapkan oleh Peraturan Daerah Nomor 18 Tahun 2011 Tentang RTRW Kota Bandung adalah menyusun peraturan zonasi, ketentuan teknis, standar teknis, kualitas ruang, dan standar kinerja sebagai rujukan bagi penerbitan izin yang lebih efisien, efektif dan akuntabel. Hal ini memperlihatkan bahwa, Peraturan Daerah Kota Bandung Nomor 18 Tahun 2011 tentang RTRW Kota Bandung 2011 - 2031 tidak dapat berdiri sendiri untuk dapat diimplementasikan secara menyeluruh, namun diperlukan adanya peraturan pelaksana yang mengatur lebih teknis agar pengaturan Tata Kota efektif, efisien dan akuntabel.

RTBL seperti juga perangkat peraturan pelaksana penataan ruang lainnya, memiliki ciri dan fungsi yang hanya dimiliki oleh RTBL. Hal ini dapat juga menjadi tawaran solusi dalam memecahkan permasalahan penataan ruang kota.

\section{Penataan Ruang dan Rencana Tata Bangunan dan Lingkungan (RTBL)}

Bagaimana RTBL dapat menjadi salah satu pemecah permasalah penataan ruang dapat dikaji menggunakan aturan terkait tentang RTBL: kedudukan, fungsi dan tujuan RTBL dapat dilihat pada uraian berikut ini. 


\section{RTBL Berdasarkan Undang-Undang Nomor 28 Tahun 2002 Tentang Bangunan Gedung}

Undang-undang Nomor 28 Tahun 2002, Pasal 1 angka 14 menjelaskan,

“ RTBL adalah panduan rancang bangun suatu kawasan untuk mengendalikan pemanfaatan ruang yang memuat rencana program bangunan dan lingkungan, rencana umum dan panduan rancangan, rencana investasi, ketentuan pengendalian rencana, dan pedoman pengendalian pelaksanaan."

Marihot Siahaan ${ }^{13}$ menyebutkan, Undang-undang Nomor 28 Tahun 2002 lahir dengan pertimbangan bahwa bangunan gedung penting sebagai tempat manusia melakukan kegiatannya untuk mencapai berbagai sasaran yang menunjang terwujudnya tujuan pembangunan nasional. Tujuan tersebut adalah mewujudkan masyarakat adil dan makmur yang merata material dan spiritual berdasarkan Pancasila dan Undang-Undang Dasar 1945.

Tujuan tersebut di atas dapat dicapai dengan penyelenggaraan bangunan gedung secara, "tertib, diwujudkan sesuai dengan fungsinya, serta dipenuhi persyaratan administrasi dan teknis bangunan gedung14". Fungsi dari bangunan gedung menyangkut aktivitas masyarakat, diantaranya: fungsi hunian; fungsi keagamaan; fungsi usaha; fungsi sosial dan budaya; serta fungsi khusus.

Fungsi tersebut diatas akan berkaitan dengan tujuan diterbitkannya Peraturan Menteri Pekerjaan Umum Nomor 29 Tahun 2006 Tentang Pedoman Persyaratan Teknis Bangunan Gedung, dimana disebutkan,

"Pembangunan bangunan gedung di atas dan/atau di bawah tanah, air dan/atau prasarana/sarana umum harus sesuai dengan rencana tata ruang wilayah dan/atau rencana teknik ruang kabupaten/kota, dan/atau RTBL.15"

\footnotetext{
13 Marihot Pahala Siahaan, supra catatan no.7, pada 2.

14 Marihot Pahala Siahaan, supra catatan no.7, pada 2.

15 Id., hlm. 14.
} 
Menurut Marihot Pahala Siahaan ${ }^{16}$, RTBL merupakan pengaturan sebagai tindak lanjut dari RTRW kabupaten/kota dan atau RDTR, digunakan untuk mengendalikan pemanfaatan suatu kawasan dan sebagai panduan rancangan kawasan untuk mewujudkan kesatuan karakter dengan aspek fungsional, sosial, ekonomi, dan ekosistem.

Apa yang dipaparkan dalam Undang-undang Bangunan Gedung memperlihatkan kepada masyarakat jika RTBL merupakan peraturan pelaksana dari RTRW (atau RDTR) dan RTBL memuat program pembangunan dan lingkungan. Secara teknis bangunan gedung merupakan perangkat yang diperlukan masyarakat untuk mengadakan kegiatan, dimana Undang-Undang Bangunan Gedung telah mengklasifikasi fungsi-fungsi bangunan gedung yang dapat dimanfaatkan oleh masyarakat.

Ketika kebutuhan masyarakat dapat langsung dirasakan melalui dibentuknya RTBL, pada saat itu pula tujuan dari pengaturan penataan ruang berlangsung, diasumsikan juga telah mencapai tujuan untuk memenuhi kebutuhan masyarakat sebagai penjamin kepastian hukum dan mencapai ketertiban masyarakat.

\section{RTBL Berdasarkan Undang-Undang Nomor 26 Tahun 2007 Tentang Penataan Ruang}

Undang-undang Nomor 26 Tahun 2007 tentang Penataan Ruang. Bab VI Pelaksanaan penataan ruang, perencanaan tata ruang, Pasal 14 ayat (3) huruf c menyebutkan bahwa rencana tata ruang terdiri dari rencana umum dan rencana rinci, dimana pada huruf c dijelaskan, salah satu dari rencana rinci tata ruang tersebut dapat dibentuk rencana detail tata ruang kabupaten/kota dan rencana tata ruang kawasan strategis kebupaten/kota, dimana RTDR ini menjadi dasar bagi penyusunan peraturan zonasi (ayat 6).

16 Id., hlm. 119. 
Dijelaskan juga pada Undang-undang Nomor 26 Tahun 2007, Pasal 14 ayat (5), bahwa rencana rinci tata ruang dapat disusun apabila:

a. Rencana umum tata ruang belum dapat dijadikan dasar dalam pelaksanaan pemanfaatan ruang dan pengendalian pemanfaatan ruang dan/atau;

b. Rencana umum tata ruang mencakup wilayah perencanaan yang luas dan skala peta dalam rencana umum tata ruang tersebut memerlukan perincian sebelum dioperasionalkan.

Bagaimana rencana rinci dan peraturan zonasi dapat berkaitan dengan pembentukan RTBL akan dipaparkan dalam artikel ini pada penjelasan lebih lanjut di angka 3 tentang Peraturan Pemerintah Nomor 15 Tahun 2010 Tentang Penyelenggaraan Penataan Ruang dan Peraturan Menteri Nomor 6 Tahun 2007 Tentang Rencana Tata Bangunan dan Lingkungan.

\section{RTBL Berdasarkan Peraturan Pemerintah Nomor 15 Tahun 2010 Tentang Penyelenggaraan Penataan Ruang}

Seperti disampaikan pada paparan artikel angka 2 tentang Undang-undang Nomor 26 Tahun 2007 Tentang Penataan Ruang di atas, keterkaitan antara Pengaturan zonasi dengan pembentukan RTBL dapat dilihat pada ketentuan umum Pasal 1 angka 15, bahwa dijelaskan:

"Pengaturan zonasi adalah ketentuan tentang persyaratan pemanfaatan ruang sektoral dan ketentuan persyaratan pemanfaatan ruang untuk setiap blok/zona peruntukan yang penetapan zonanya dalam rencana rinci tata ruang."

Pada Pasal 1 angka 16, dijelaskan pengertian mengenai peraturan zonasi:

"Peraturan zonasi adalah ketentuan yang mengatur tentang persyaratan pemanfaatan ruang dan ketentuan pengendaliannya dan disusun untuk setiap blok/zona peruntukan yang penetapan zonanya dalam rencana rinci tata ruang." 
Penataan ruang mengatur juga perencanaan berdasarkan zonasi ataupun blok pada sebuah wilayah/kawasan, pengaturan zonasi atau blok diperuntukkan untuk perencanaan tata ruang yang lebih rinci.

Kaitan Rencana rinci dengan RTBL berada pada Peraturan Pemerintah Nomor 15 tahun 2010 tentang Penyelenggaraan Penataan Ruang, Peraturan Pemerintah tersebut telah lebih eksplisit mengeluarkan bagaimana penyusunan RTBL dalam batang tubuhnya. Pasal 41 Peraturan pemerintah ini menyatakan:

"Rencana rinci tata ruang kabupaten/kota merupakan dasar penyusunan rencana tata bangunan dan lingkungan bagi zona-zona yang pada rencana rinci tata ruang ditentukan sebagai zona yang penanganannya diprioritaskan."

Kemudian berdasarkan Pasal 59 ayat (5) ditegaskan ulang bahwa penyusunan beranjak dari RDTR:

"Rencana detail tata ruang merupakan dasar penyusunan rencana tata bangunan dan lingkungan bagi zona-zona yang pada rencana detail tata ruang ditentukan sebagai zona yang penanganannya diprioritaskan."

Berdasarkan paparan angka 1 hingga 3 diatas terdapat beberapa istilah yang harus diperhatikan berkaitan dengan pembentukan RTBL, yakni penataan ruang rinci, penataan ruang dalam blok dan penataan ruang berdasarkan zonasi. Istilah tersebut menunjukkan bahwa RTBL merupakan peraturan pelaksana dari RTRW yang mengatur secara umum.

\section{RTBL Berdasarkan Peraturan Menteri Nomor 6 Tahun 2007 Tentang Rencana Tata Bangunan dan Lingkungan}

Peraturan Menteri Nomor 6 Tahun 2007 Tentang Rencana Tata Bangunan dan Lingkungan menjelaskan bahwa seluruh rencana, rancangan, aturan, dan mekanisme dalam penyusunan Dokumen RTBL harus merujuk pada pranata pembangunan yang lebih tinggi, baik pada lingkup kawasan, kota, maupun 
wilayah dan berdasarkan paparan sebelumnya, dapat terlihat jika RTBL merupakan peraturan pelaksana dari RTRW dan/atau RDTR.

Pedoman teknis tentang RTBL yang terdapat pada Peraturan Menteri Nomor 6 Tahun 2007 ini bertujuan untuk dapat mewujudkan bangunan gedung sesuai fungsi yang ditetapkan dan yang memenuhi persyaratan teknis, yaitu meliputi persyaratan peruntukan dan intensitas bangunan, arsitektur dan lingkungan, serta keandalan bangunan ${ }^{17}$. Pada batang tubuh Peraturan Menteri Nomor 6 Tahun 2007 dijelaskan mengenai materi yang harus termuat dalam setiap pembentukan RTBL. Materi tersebut dijelaskan pada Pasal 3 ayat (1) , yaitu:

"Materi pokok Rencana Tata Bangunan dan Lingkungan meliputi:
a. Program Bangunan dan Lingkungan;
b. Rencana Umum dan Panduan Rancangan;
c. Rencana Investasi;
d. Ketentuan Pengendalian Rencana;
e. Pedoman Pengendalian Pelaksanaan."

Pasal 3 ayat (1) huruf b mengatur mengenai materi rencana umum dan panduan rancangan, dimana Panduan Rancangan merupakan penjelasan lebih rinci atas Rencana Umum yang telah ditetapkan sebelumnya dalam bentuk penjabaran materi utama melalui pengembangan komponen rancangan kawasan pada bangunan, kelompok bangunan, elemen prasarana kawasan, kaveling dan blok, termasuk panduan ketentuan detail visual kualitas minimal tata bangunan dan lingkungan. Disinilah penempatan dari istilah yang sebelumnya dijelaskan dalam paparan angka 3 (tiga) ${ }^{18}$, pengaturan panduan zonasi, blok atau kaveling akan tercantum pada Peraturan RTBL bagian rencana umum dan panduan rancangan.

\footnotetext{
${ }^{17}$ Marihot Pahala Siahaan, supra catatan no.7, pada 13.

18 Berdasarkan paparan angka 1 hingga 3 diatas terdapat beberapa istilah yang harus diperhatikan berkaitan dengan pembentukan RTBL, yakni penataan ruang rinci, penataan ruang dalam blok dan penataan ruang berdasarkan zonasi. Istilah tersebut menunjukkan bahwa RTBL merupakan peraturan pelaksana dari RTRW yang mengatur secara umum.
} 
Pada Peraturan Menteri No. 6 Tahun 2007 tentang Pedoman Umum Rencana Tata Bangunan dan Lingkungan kedudukan RTBL berada pada tingkat hirarki di bawah RTRW. Kedudukan RTBL dapat dilihat pada bagan di bawah ini.

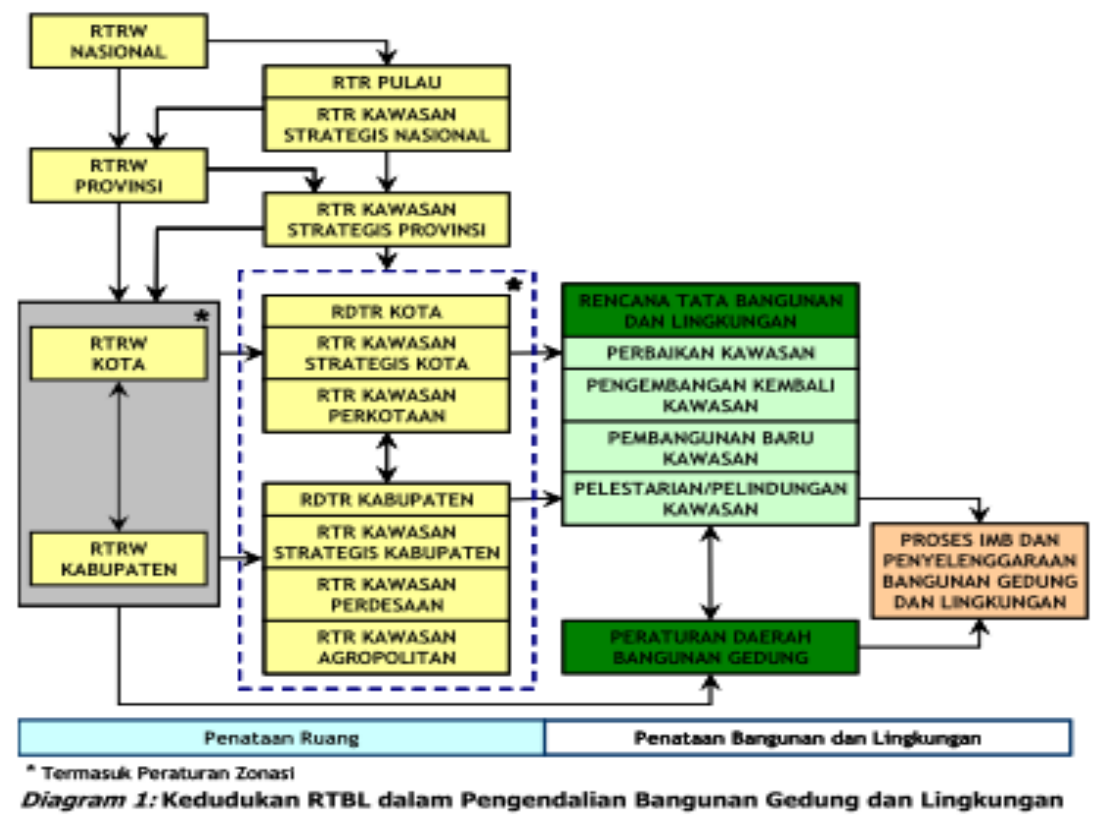

Peraturan Menteri Nomor 6 tahun 2007, pada Pasal 5 ayat (4) menjelaskan bahwa dokumen RTBL ditetapkan dengan peraturan Bupati/Walikota, dan untuk Daerah Khusus Ibukota Jakarta dengan peraturan Gubernur. Berdasarkan pada Peraturan Menteri tersebut, terdapat kriteria kawasan yang termasuk dalam pembentukan RTBL, yakni: kawasan baru berkembang cepat; kawasan terbangun; kawasan dilestarikan; kawasan rawan bencana; dan kawasan gabungan atau campuran dari keempat jenis kawasan pada butir (a), (b), (c) dan/atau (d).

\section{RTBL Berdasarkan Peraturan Daerah Kota Bandung Nomor 5 Tahun 2010 Tentang Bangunan Gedung}

Pada akhirnya, pelaksanaan peraturan akan diharmonisasi dengan peraturan lainnya, Peraturan Daerah Kota Bandung Nomor 5 Tahun 2010 tentang 
Bangunan Gedung merupakan peraturan daerah yang secara hirarki melaksanakan peraturan yang lebih tinggi.

Peraturan pemerintah Nomor 36 Tahun 2005 merupakan peraturan pelaksana dari Undang-undang Nomor 28 Tahun 2002 Tentang Bangunan Gedung dan Rancangan Peraturan Walikota atau bupati akan menjadi bentuk produk peraturan daerah RTBL dari Peraturan Daerah Kabupaten/Kota Tentang Bangunan Gedung.

Berikut cuplikan isi pasal dari Peraturan Daerah Kota Bandung Nomor 5 Tahun 2010 tentang Bangunan gedung yang menyatakan mengenai pembentukan RTBL, Pasal 8 menyebutkan,

“(1) Fungsi dan klasifikasi bangunan gedung harus sesuai dengan peruntukan lokasi yang diatur dalam RTRW, RDTR, RTBL dan/atau Peraturan setempat.

(2) Walikota menetapkan fungsi dan/atau perubahan fungsi bangunan gedung, kecuali bangunan gedung fungsi khusus.

(3) Penetapan fungsi bangunan khusus ditetapkan oleh Pemerintah."

Pasal 17 menyebutkan,

“....(5) Dalam hal RTRW, RDTR, RTRK dan/atau peraturan bangunan setempat dan RTBL belum ditetapkan, maka Walikota dapat memberikan persetujuan membangun bangunan gedung dengan pertimbangan:

a. Persetujuan membangun tersebut bersifat sementara sepanjang tidak bertentangan dengan ketentuanketentuan tata ruang yang lebih makro, kaidah perencanaan kota dan penataan bangunan;

b. Walikota segera menyusun dan menetapkan RDTR, peraturan bangunan setempat dan RTBL berdasarkan RTRW;

c. Apabila persetujuan yang telah diberikan terdapat ketidaksesuaian dengan rencana tata ruang dan tata bangunan yang ditetapkan kemudian, maka perlu diadakan penyesuaian dengan resiko ditanggung oleh pemohon/pemilik bangunan..."; 
Pasal 17 ayat 5 huruf b Peraturan Daerah Kota Bandung Nomor 5 Tahun 2010 Tentang Bangunan Gedung merupakan amanat untuk menyusun RTBL telah tertuang dengan eksplisit. Dalam hal kota Bandung telah memiliki Peraturan Daerah Nomor 18 Tahun 2011 Tentang RTRW Kota Bandung Tahun 2011 - 2031, maka penyusunan Peraturan Walikota Tentang RTBL untuk kawasan/wilayah Kota Bandung dapat berdasar pada RTRW Kota Bandung.

\section{RTBL Berdasarkan Peraturan Daerah Kota Bandung Nomor 18 Tahun 2011 Tentang Rencana Tata Ruang Wilayah Kota Bandung 2011-2031.}

Rencana Tata Bangunan dan Lingkungan (RTBL) merupakan perangkat yang tidak dikenal secara umum seperti Rencana Tata Ruang dan Wilayah (RTRW) ataupun Rencana Detil Tata Ruang (RDTR). RTBL berkedudukan sebagai peraturan pelaksana harus mengacu pada RTRW dan/atau RDTR. Sebagai contoh, dapat dilihat pada RTRW Kota Bandung, Peraturan Daerah Nomor 18 Tahun 2011 tentang RTRW Kota Bandung 2011-2031.

Pada Bab VII, Arahan pemanfaatan ruang wilayah kota, dalam mewujudkan pusat pelayanan kegiatan kota, Pasal 74 ayat (2) berbunyi,

"Untuk mewujudkan optimalisasi fungsi dan pelayanan PPK, diarahkan untuk menyusun Rencana Tata Bangunan dan Lingkungan (RTBL) atau Panduan Rancang Kota untuk kegiatan berskala besar atau berdampak penting dalam PPK Alun-Alun dan PPK Gedebage".

Pasal 74 ayat (4),

"Mengarahkan untuk menyusun program dalam mengembangkan SPK dan PL dilakukan dengan huruf (d) menyusun RTBL atau Panduan Rancang Kota untuk setiap SPK."

Lebih lanjut Pada Bab VIII, pengendalian pemanfaatan ruang wilayah, Pasal 93 ayat (3), 
"Untuk melakukan rujukan pengendalian yang lebih teknis, penjabaran RTRW dilakukan dalam_Huruf (a) RDTRK dan/ atau RTBL; dan (b) perangkat pengendalian, antara lain Peraturan Zonasi, pengkajian rancangan, Panduan Rancang Kota dan/atau standar teknis yang ditetapkan".

Kota Bandung telah memiliki dasar hukum untuk menyusun peraturan tentang RTBL sesuai dengan amanat yang tercantum pada Peraturan Daerah tentang RTRW Kota Bandung, bahkan secara jelas Pasal 74 ayat (2) mengamanatkan untuk membentuk RTBL untuk kawasan Alun-Alun dan Gedebage. Contoh yang terdapat di Kota Bandung dapat menjadi gambaran pembentukan peraturan tentang RTBL di Kabupaten/kota lainnya.

RTBL sebagai peraturan pelaksana akan keluar sebagai produk hukum berupa Peraturan Daerah atau Peraturan Kepala Daerah (Peraturan Bupati atau peraturan Walikota). Sebagai contoh, dapat dilihat pada Peraturan Daerah Kota Bandung Nomor 5 Tahun 2010 Tentang Bangunan Gedung, Pasal 17 ayat (5), disebutkan,

“....(5) Dalam hal RTRW, RDTR, RTRK dan/atau peraturan bangunan setempat dan RTBL belum ditetapkan, maka Walikota dapat memberikan persetujuan membangun bangunan gedung dengan pertimbangan:

a. Persetujuan membangun tersebut bersifat sementara sepanjang tidak bertentangan dengan ketentuan-ketentuan tata ruang yang lebih makro, kaidah perencanaan kota dan penataan bangunan;

b. Walikota segera menyusun dan menetapkan RDTR, peraturan bangunan setempat dan RTBL berdasarkan RTRW;".

Peraturan Daerah Kota Bandung mengenai Bangunan Gedung dan RTRW Kota Bandung yang telah dipaparkan di atas, memperlihatkan keterkaitan antara RTRW dengan RTBL, RTRW mengamanatkan RTBL untuk disusun agar pengaturan tata ruang yang lebih rinci dapat dilaksanakan.

Berdasarkan pemaparan sebelumnya, RTBL sebagai salah satu dari instrumen hukum penataan ruang, tergambarkan mempunyai kedudukan dan 
fungsi yang penting. Keterkaitan antara satu peraturan dengan peraturan lainnya saling melengkapi dan mendukung untuk dibentuk sebuah peraturan tentang RTBL sebagai peraturan pelaksana dari RTRW.

\section{Penerapan RTBL di Lapangan}

Bahwa RTBL harus disusun sebagai perangkat aturan pelaksana tentunya tidak luput dari kendala. Apabila perangkat tentang RTRW dapat disusun sesuai dengan waktu yang ditetapkan, seringkali tidak demikian dengan penyusunan peraturan $\mathrm{RTBL}^{19}$. Berikut adalah permasalahan mengenai pelaksanaan RTBL menurut pendapat para pelaku teknis.

1. Seorang arsitek Bayu Arie Wibawa, ST, MT, IAI"20, menyatakan, "Sering kali pengaturan bangunan (tinggi, KDB ${ }^{21}, \mathrm{KLB}^{22}$, sempadan, dll) diterapkan hanya berdasar pada produk-produk rencana tata ruang seperti RTRW, RUTRK, RDTRK, dan RTRK. Dengan sifat perencanaan dua dimensinya, maka beberapa aspek teknis yang terkait dengan analisis tiga dimensi bangunan praktis "diabaikan". RTBL sebagai manifestasi perancangan kota (urban desain) merupakan "jembatan" antara perencanaan tata ruang kota (urban planning) dengan arsitektur bangunan (architecture). Dengan basis perancangan tiga dimensi yang dimilikinya serta penekanan pada potensi

19 Hal ini dibuktikan dengan amanat yang terdapat pada RTRW Kota Bandung (Perda Kota Bandung No.18 Tahun 2011) bahwa terdapat arahan untuk membentuk RTBL, diantaranya adalah RTBL Kawasan ALun-Alun, RTBL Kawasan Gede Bage, RTBL Kawasan Cibaduyut, namun hingga penghujung tahun 2015 belum dapat dilaksanakan.

20 Bayu Arie Wibawa, RTBL Sebagai Alat Perancangan Kota "IDEAL" Untuk Pengaturan Bangunan dan Lingkungannya, http://www.inkindo-jateng.web.id/?p=792

21 Marihot Pahala Siahaan, Hukum Bangunan Gedung di Indonesia 22.(RajaGrafindo Persada, Jakarta, 2008). Koefisien Dasar Bangunan atau KDB adalah angka persentase perbandingan antara luas seluruh lantai dasar bangunan gedung dan luas lahan/tanah perpetakan/daerah perencanaan yang dikuasi sesuai rencana tata ruang dan rencana tata bangunan dan lingkungan.

22 Id., 23. Koefisien Luas Bangunan atau KLB adalah angka persentase perbandingan antara luas seluruh lantai bangunan gedung dan luas tanah perpetakan/daerah perencanaan yang dikuasai sesuai rencana tata ruang dan rencana tata bangunan dan lingkungan 
dan kendala lokal, menjadikan produk RTBL dinilai lebih tepat untuk pengaturan bangunan."

Pada pengaturan bangunan telah banyak ditetapkan aturan-aturan mengenai IMB, HO, peraturan beton, baja, dan lain-lain. Pada sisi tata ruang kota juga telah ada berbagai aturan tingkatan tata ruang mulai dari RTRW sampai RTRK. Di antara dua sisi pengaturan ini, maka terdapat "grey area" yang belum dapat diatur secara jelas dan tegas seperti jalur pedestrian, ruang terbuka publik pada kapling bangunan, reklame, street furniture, desain PKL, corak arsitektur lingkungan setempat, landmark kawasan, dan lain-lain. Melalui RTBL pengaturan elemen-elemen yang mengkaitkan antara bangunan dan kota dapat diatur dengan detail dan jelas.

2. Kasubdit Perencanaan Teknis Dit.PBL Dian Irawati23, pada Workshop Rencana Tata Bangunan dan Lingkungan (RTBL) di Werdhapura Sanur Bali, Senin 14 Juli 2014 yang diselenggarakan oleh Direktorat Penataan Bangunan dan Lingkungan (PBL) Ditjen Cipta Karya, Kementerian PU. Dian mengatakan, RTBL sebagai produk ideal dalam upaya pengaturan bangunan dan lingkungan kawasan kota tidak dapat terlepas dari berbagai kendala dalam penyusunan dan terlebih lagi dalam tahap pelaksanaannya. Hal ini terjadi mengingat dalam produk perancangan yang dihasilkan terjadi persinggungan langsung antara kepentingan publik dan privat.

"Keberhasilan pengaturan bangunan melalui RTBL sangat tergantung pada kemampuan perencana, kesungguhan pelaksana serta peran serta masyarakat dan investor. Tanpa diikuti sinergi semua stakeholder maka produk RTBL hanya akan menjadi dokumen rapi yang tersimpan di dinas/instansi Pemerintah Daerah atau Kota," tegas Dian.

${ }^{23}$ Galih-Rentek, Dokumen RTBL Untuk Mendukung Perwujudan Permukiman Layak Huni dan Berkelanjutan, http://ciptakarya.pu.go.id/water/post.php?q=3905-Dokumen-RTBL-Untuk-Mendukung. html 
Kedua pernyataan di atas menjelaskan kelebihan yang terdapat pada RTBL. Kekuatan atau kelebihan yang dimiliki RTBL antara lain:

a. Produk RTBL mengeluarkan tampilan rancang kota dalam bentuk 3 (tiga) dimensi. Perancangan yang memberikan gambaran nyata terhadap lokasi perencanaan, tingkat kedetilan dari perancanaan tentu diharapkan semirip mungkin dengan keadaan dan situasi di lapangan.

b. Produk RTBL berhadapan langsung dengan kepentingan masyarakat. Persinggungan perangkat RTBL dengan kepentingan masyarakat diharapkan dapat mengakomodir kebutuhan masyarakat baik kebutuhan publik maupun privat, memerlukan dukungan dan kerjasama dari berbagai pihak.

Kelebihan yang dimiliki oleh RTBL sebagai salah satu perangkat pelaksanaan dari undang-undang penataan ruang pada implementasinya berhadapan dengan beberapa kendala. Kendala tersebut yakni:

a. Rancangan kota 3 dimensi yang rinci membutuhkan waktu, perangkat dan pelaksanaan teknis yang utuh dan komprehensif di lapangan, sehingga implementasi RTBL seringkali mengambil tenggat waktu yang lama sedangkan dinamika ruang berjalan dengan cepat.

b. Persinggungan langsung dengan masyarakat untuk menemukan kepentingan yang memadai bagi seluruh lapisan masyarakat di sebuah kawasan tidak dapat diselenggarakan secara terburu-buru dan singkat.

Selain dari kendala tersebut di atas, penulis menemukan kendala lain di lapangan antara lain: sebagai peraturan pelaksana, banyak ditemukan benturan dengan peraturan pelaksana lain; semakin rinci sebuah penataan, proses penyusunan mengalami banyak kendala di lapangan, terutama ketika kebutuhan masyarakat di daerah perencanaan saling berbenturan; terdapatnya kekosongan atau tumpang tindih kewenangan pada lembaga dan unit pelaksana teknis terkait penataan ruang ketika hendak melakukan implementasi RTBL (dalam hal pengelolaan hingga pengawasan); dan apabila perencanaan terlalu rinci, ketika 
terjadi perubahan di daerah perencanaan, akan sukar untuk dilakukan revisi atau pembenahan.

\section{Fungsi Instrumen RTBL Berdasarkan Peraturan Menteri Pekerjaan Umum Nomor 6 Tahun 2007 Tentang Pedoman Umum Rencana Tata Bangunan dan Lingkungan}

Kegiatan Penataan Bangunan dan Lingkungan adalah kegiatan yang bertujuan mengendalikan pemanfaatan ruang dan menciptakan lingkungan yang tertata, berkelanjutan, berkualitas serta menambah vitalitas ekonomi dan kehidupan masyarakat. Oleh karenanya penyusunan dokumen RTBL, selain sebagai pemenuhan aspek legal-formal, yaitu24:

A. sebagai produk pengaturan pemanfaatan ruang serta penataan bangunan dan lingkungan pada kawasan terpilih;

B. sebagai dokumen panduan/pengendali pembangunan dalam penyelenggaraan penataan bangunan dan lingkungan kawasan terpilih agar memenuhi kriteria perencanaan tata bangunan dan lingkungan yang berkelanjutan yang meliputi, pemenuhan persyaratan tata bangunan dan lingkungan, peningkatan kualitas hidup masyarakat melalui perbaikan kualitas lingkungan dan ruang publik, perwujudan pelindungan lingkungan, serta peningkatan vitalitas ekonomi lingkungan;

C. bermanfaat untuk mengarahkan jalannya pembangunan sejak dini;

D. mewujudkan pemanfaatan ruang secara efektif, tepat guna, spesifik setempat dan konkret sesuai dengan rencana tata ruang wilayah;

E. melengkapi peraturan daerah tentang bangunan gedung;

F. mewujudkan kesatuan karakter dan meningkatkan kualitas bangunan gedung dan lingkungan/kawasan;

G. mengendalikan pertumbuhan fisik suatu lingkungan/kawasan;

24 Bahan laporan akhir bab pendahuluan Rancangan Rencana Tata Bangunan dan Lingkungan Kawasan ITB Bandung. 
H. menjamin implementasi pembangunan agar sesuai dengan aspirasi dan kebutuhan masyarakat dalam pengembangan lingkungan/kawasan yang berkelanjutan; dan

I. menjamin terpeliharanya hasil pembangunan pasca pelaksanaan, karena adanya rasa memiliki dari masyarakat terhadap semua hasil pembangunan.

Fungsi lain dari perangkat RTBL berada pada tingkat kepastian pembiayaan yang dimiliki. Seringkali kendala pembiayaan menjadi salah satu alasan terhambatnya pembangunan tata ruang yang baik dan memadai, namun kendala ini telah diwadahi oleh perangkat RTBL 25.

Materi pokok mengenai rencana investasi merupakan materi yang harus terdapat dalam peraturan tentang RTBL, dimana pada rencana investasi tersebut peraturan telah mempertimbangan hal-hal berikut ini:

a. Rencana investasi disusun berdasarkan dokumen RTBL yang memperhitungkan kebutuhan nyata para pemangku kepentingan dalam proses pengendalian investasi dan pembiayaan dalam penataan lingkungan/kawasan;

b. Rencana ini merupakan rujukan bagi para pemangku kepentingan untuk menghitung kelayakan investasi dan pembiayaan suatu penataan atau pun menghitung tolok ukur keberhasilan investasi, sehingga tercapai kesinambungan pentahapan pelaksanaan pembangunan;

c. Rencana ini menjadi alat mobilisasi dana investasi masing-masing pemangku kepentingan dalam pengendalian pelaksanaan sesuai dengan kapasitas dan perannya dalam suatu sistem wilayah yang disepakati

25 Sebagaimana telah dijelaskan bahwa Rencana Tata Bangunan dan Lingkungan (RTBL) merupakan panduan rancang banging suatu lingkungan/kawasan yang dimaksudkan untuk mengendalikan pemanfaatan ruang, penataan bangunan dan lingkungan yang memuat materi pokok: a. ketentuan program bangunan dan lingkungan; b. rencana umum dan panduan rancangan; c. rencana investasi; d. ketentuan pengendalian rencana; dan e.pedoman pengendalian pelaksanaan pengembangan lingkungan/kawasan. 
bersama, sehingga dapat tercapai kerja sama untuk mengurangi berbagai konflik kepentingan dalam investasi/ pembiayaan; dan

d. Rencana investasi juga mengatur upaya percepatan penyediaan dan peningkatan kualitas pelayanan prasarana/sarana dari suatu lingkungan/kawasan.

Selain materi tersebut di atas harus tercantum pada peraturan tentang RTBL yang akan disusun, RTBL juga sudah menetapkan teknis pelaksanaan investasi ${ }^{26}$, yakni:

a. Program perencanaan bersifat jangka menengah, minimal untuk kurun waktu

5 (lima) tahun dan telah mengindikasikan investasi untuk berbagai macam kegiatan, yang meliputi:

1) Tolak ukur pekerjaan;

2) Besaran rencana pembiayaan;

3) Perkiraan waktu pelaksanaan; dan

4) Kesepakatan sumber pendanaan.

b. Pembiayaan investasi pembangunan direncanakan berdasarkan:

1) Pihak pemerintah daerah/pusat (dari berbagai sektor);

2) Pihak dunia usaha/swasta; dan

3) Masyarakat.

c. Teknis pola penggalangan dana;

d. Teknis tata cara penyiapan dan penyepakatan investasi; hingga

e. Menuntun para pemangku kepentingan dalam memperoleh justifikasi kelayakan ekonomi dan usulan perencanaan lingkungan.

Fungsi pembiayaan melalui rencana investasi yang dimiliki RTBL merupakan salah satu fungsi yang juga menjadi ciri khas yang hanya dimiliki oleh RTBL sebagai salah satu perangkat penataan ruang.

${ }^{26}$ Buku Pedoman Umum Rencana Tata Bangunan Dan Lingkungan. Peraturan Menteri Pekerjaan Umum Nomor 6 tahun 2007, hlm. 52. 


\section{Instrumen RTBL dan Lingkungan Hidup}

Sebagai pelengkap, pada saat ini, menjaga kondisi dan kualitas lingkungan menjadi prioritas pada setiap lapisan kegiatan. Penataan ruang diharapkan dapat menjadi salah satu gerbang untuk turut menjaga kondisi dan kualitas lingkungan ini. Konsep-konsep ramah lingkungan yang ditegaskan melalui prinsip pembangunan berkelanjutan pada Undang-undang Lingkungan Hidup Nomor 32 Tahun 2009, diimplementasikan juga dalam RTBL, hal ini menjadi salah satu fungsi dari penyelenggaraan RTBL.

Konsep lingkungan yang diimplementasikan dalam RTBL adalah kota hijau ${ }^{27}$ (kota berkelanjutan), yakni merupakan kota yang dibangun dengan tidak mengorbankan aset kota, melainkan terus menerus memupuk semua kelompok aset meliputi manusia, lingkungan terbangun, sumber daya alam, lingkungan dan kualitas prasarana perkotaan.

Kota hijau juga dapat dipahami sebagai kota yang ramah lingkungan berdasarkan perencanaan dan perancangan kota yang berpihak pada prinsipprinsip pembangunan berkelanjutan, antara lain dengan memanfaatkan secara efektif dan efisien sumber daya air dan energi, mengurangi limbah, menerapkan sistem transportasi terpadu, menjamin kesehatan lingkungan, dan mensinergikan lingkungan alami dan buatan.

RTBL adalah sebuah produk pengaturan yang disusun dan diharapkan dapat mensinergikan seluruh perencanaan yang ada di suatu kawasan sehingga dapat mendukung dan memberikan kontribusi terhadap terwujudnya kota hijau yang berkelanjutan; dan RTBL adalah juga merupakan upaya konservasi kawasan berskala lingkungan dalam dokumen yang disusun sesuai Pedoman RTBL (Peraturan Menteri Pekerjaan Umum Nomor 06/PRT/M/2007).

Upaya tersebut diharapkan tercapai dengan fokus pada penciptaan ide-ide kreatif sebagai target hijau kawasan yang menciptakan suasana kondusif dalam

27 Bahan laporan akhir bab pendahuluan Rancangan Rencana Tata Bangunan dan Lingkungan Kawasan ITB Bandung. 
rangka pembangunan bangunan gedung hijau; fokus pada desain lingkungan yang dapat menghemat penggunaan sumber daya tak terbarukan/fossil fuel; dan detail tata cara pelaksanaan di tingkat basis masyarakat untuk mencapai target sasaran "hijau di wilayahnya" 28.

\section{Penutup}

Untuk mengatur ruang beserta masyarakatnya diperlukan sebuah aturan dalam bentuk hukum. Untuk tujuan inilah, terbentuk Hukum Tata Ruang (HTR) seperti yang disampaikan oleh Yunus Wahid, "Hukum Tata Ruang adalah keseluruhan peraturan hukum yang mengatur tentang proses perencanaan, peruntukan, pemanfaatan, serta pengendalian dan pengawasan pemanfaatan ruang."29. Hukum Tata Ruang sebagai sarana diharapkan berfungsi dalam mendukung tercapainya tujuan penataan ruang ${ }^{30}$.

Rencana Tata Ruang Wilayah Kota (RTRWK) menjadi acuan bagi pelaksanaaan kegiatan para penduduk kotanya. Negara Indonesia yang terdiri dari beragam suku bangsa, memiliki beragam karakter, faktor keragaman karakter ini dapat membentuk sebuah kota. Menurut Zoe'raini Djamal Irwan, M.Si ${ }^{31}$, Kota merupakan sebuah sistem yaitu sistem terbuka, baik secara fisik maupun sosial ekonomi, bersifat tidak statis dan dinamis atau bersifat sementara. Dalam perkembangannya, kota sukar untuk dikontrol dan sewaktu-waktu dapat

${ }^{28}$ Id. Konsep Kota Hijau merupakan konsep yang digunakan sebagai Bahan laporan akhir bab pendahuluan Rancangan Rencana Tata Bangunan dan Lingkungan Kawasan ITB Bandung dan RTBL Alun-ALun Bandung.

29 Yunus Wahid, Pengantar Hukum Tata Ruang 79 (Kencana, Jakarta, 2014). Rumusan tentang "Hukum Tata Ruang" ini, dikemukakan sebagai bahan kuliah Hukum Tata Ruang pada Fakultas Hukum Unhas, 25 April 2005, kemudian dilanjutkan dengan perbaikan seperlunya pada 15 Februari 2007, 28 Februari 2008 dan terakhir 29 Januari 2009. Masukan dari pembaca yang budiman, berkaitan dengan penyempurnaan definisi ini, senantiasa diharapkan sebagai gambaran, pada 2009, dicoba memperbaiki dengan mendahulukan karta "awasan" dari "pengendalian" sebagai berikut: “..., pengawasan dan pengendalian pemanfaatan ruang”, dengan pengertian bahwa dalam pemanfaatan ruang diawasi untuk dikendalikan, tetapi kemudian disadari bahwa yang diawasi termasuk pengendalian pemanfaatan itu sendiri, sehingga pengertian yang dirumuskan 28 Februari 2008 dipertahankan sampai saat ini.

30 Id., hlm. 80.

${ }^{31}$ Zoe'raini Djamal Irwan, Tantangan Lingkungan dan Lansekap Kota 31 (2004). 
menjadi tidak beraturan. Kota merupakan suatu wilayah berkembangnya kegiatan sosial, budaya dan ekonomi perkotaan yang tidak berstatus sebagai kota administratif atau kotamadya. Aktifitas dan perkembangan kota mempunyai pengaruh terhadap lingkungan fisik.

Pada dasarnya kota itu kompleks: untuk terlibat di dalamnya membutuhkan sebuah pemahaman mengenai kompleksitasnya. Hal tersebut disusun atas dasar hubungan dan konflik, persamaan dan perbedaan, mitos dan legenda, tanpa adanya hasil tambahan kecuali sinergis ${ }^{32}$. Hal inilah yang menimbulkan pertanyaan, apakah RTRW sudah cukup dapat memenuhi dan mewadahi kepentingan kota dalam mengatur penataan ruangnya? ataukah diperlukan pengaturan yang lebih rinci mengingat tingkat kompleksitas dari tipikal masyarakat berkembang.

Kompleksitas wilayah/kawasan dari kota yang berbeda-beda itu dapat berdasarkan tipologi ruang ataupun keragaman masyarakatnya. Mengambil contoh Kota Bandung, setiap kawasan memiliki karakter masyarakat yang beragam, hal ini tentunya dapat menjadikan rupa dari ruang kota yang berbedabeda. RTRW telah melihat hal tersebut, sehingga berdasarkan hirarki perundangundangan, Peraturan Daerah Nomor 18 Tahun 2011 Tentang RTRW Kota Bandung 2011-2031, keragaman tersebut diatur menggunakan peraturan pelaksana. Peraturan Daerah Nomor 18 Tahun 2011 berkedudukan sebagai pemberi arahan dan pedoman secara umum untuk seluruh Kawasan Kota Bandung.

RTBL memiliki karakter perancangan kota yang cukup rinci dan dapat mengukur kebutuhan masyarakatnya, dengan tampilan rancangan tiga dimensi sebagai salah satu produk RTBL, tentunya tingkat pemenuhan kebutuhan masyarakat dapat mencapai sasaran yang diinginkan. Pada RTBL terdapat juga rencana investasi sebagai fungsi pembiayaan, dimana pada rancangan penyusunannya, calon-calon investor pada kawasan perencanaan RTBL telah

32 Calvet, Voix de la ville. Ruang Kota Eropa dan Tantangan Masyarakat Berwawasan Ekologis. Voula Mega, hlm. 81. 
diperkenalkan untuk ikut membangun kawasan perencanaan, sehingga diharapkan ketika RTBL diimplementasikan, tidak akan terjadi kendala pembiayaan. RTBL sebagai salah satu peraturan pelaksana memiliki kelebihan yang patut untuk dipertimbangkan, dengan demikian, tulisan ini bermaksud untuk menegaskan bahwa arahan pada peraturan penataan ruang (pada RTRW) untuk menyusun RTBL sepatutnya dilaksanakan oleh pemerintah agar terselenggara penataan ruang yang baik.

Sebaik-baiknya sebuah perangkat perencanaan, jika masyarakat sebagai subjek, baik berkedudukan sebagai pihak pemerintah maupun warga masyarakat, tidak membentuk kerjasama dan kesepakatan dalam mencapai pembangunan kota, maka perencanaan RTBL-pun hanya akan menjadi sebuah dokumen perencanaan. Kesiapan itu harus timbul dari seluruh aspek dan perangkat agar tercipta tata ruang kota yang diharapkan.

\section{Daftar Pustaka}

\section{Buku:}

Budihardjo, Eko (2003), "Pengantar: Menuju Kota Yang Manusiawi dan Berwawasan Lingkungan" . Kota dan Lingkungan, Pendekatan Baru Terhadap Masyarakat Berwawasan Ekologi. Jakarta. LP3ES.

Hasni (2008). "Hukum Penataan Ruang dan Penatagunaan Tanah Jilid 1". Jakarta: PT RajaGrafindo Persada.

Hasni (2008). "Hukum Penataan Ruang dan Penatahunaan Tanah Jlid 2". Jakarta: PT RajaGrafindo Persada.

Inoguchi, Takashi, Edward Newman, dan Glen Paoletto (2003). "Pendahuluan : Kota dan Lingkungan - Menuju Kemitraan Berwawasan Ekologi". Kota dan Lingkungan, Pendekatan Baru Terhadap Masyarakat Berwawasan Ekologi. Jakarta. LP3ES.

Ridwan, Juniarso \& Achmad Sodik (2013). "Hukum Tata Ruang". Bandung: NUANSA.

Siahaan, Marihot Pahala (2008). "Hukum Bangunan Gedung di Indonesia”. Jakarta: PT RajaGrafindo Persada.

Soekanto, Soerdjono dan Sri Mamudji (1994). "Penelitian Hukum Normatif Suatu Tinjauan Singkat". Jakarta: Raja Grafindo Persada.

Wahid, A.M. Yunus (2014). "Hukum Tata Ruang”. Jakarta: Kencana. 


\section{Makalah:}

Djamal Irwan, Zoe'raini (2004), “Tantangan Lingkungan dan Lansekap Kota".CIDES. Jakarta

\section{Jurnal:}

Alfriani (2012),"Ideologi Welfare State Dalam Dasar Negara Indonesia: Analisis Putusan Mahkamah Konstitusi Terkait Sistem Jaminan Sosial Nasional". Jurnal Konstitusi Volume 9 No. 3 September 2012. Jakarta.

Barliana, M. Syaom, BetanParamita, Dodit Ardian Pancapana, Dian Cahyani (2015), "Belajar Dari Kota Surabaya: Pengukuran Kualitas Objektif Untuk Menentukan Prioritas Penataan Kota”. Jurnal Lingkungan Binaan Indonesia Volume 2 No. 1 Januari 2015.

Yusuf, Asep Warlan (2015), "Hukum dan Keadilan”. Padjajaran Jurnal Ilmu Hukum Volume 2 No.1.

\section{Peraturan Perundang-undangan:}

Undang - Undang No. 28 Tahun 2002 Tentang Bangunan Gedung

Undang - Undang No. 26 Tahun 2007 Tentang Penataan Ruang

Peraturan Pemerintah No. 36 Tahun 2005 Tentang Peraturan Pelaksana Undang Undang No. 26 Tahun 2002 Tentang Bangunan Gedung.

Peraturan Menteri Pekerjaan Umum No. 6 Tahun 2007 Tentang Pedoman Umum Rencana Tata Bangunan dan Lingkungan.

Peraturan Pemerintah Pekerjaan Umum No. 24/PRT/M/2007 Tentang Pedoman Teknis Izin Mendirikan Bangunan Gedung.

Peraturan Pemerintah No. 15 Tahun 2010 Tentang Penyelenggaraan Penataan Ruang.

Peraturan Daerah Kota Bandung No. 12 Tahun 2011 Tentang Penyelenggaraan , Retribusi Izin Mendirikan Bangunan dan Retribusi Penggantian Biaya Cetak Peta.

Peraturan Daerah Kota Bandung No. 18 Tahun 2011 Tentang Rencana Tata Ruang dan Wilayah Kota Bandung 2011-2031.

\section{Internet:}

Andy Simarmata, Hendrius. "Peran Perencanaan Dalam Proses Perencanaan Tata Ruang Yang Partisipatif”. http://penataanruang.pu.go.id/bulletin/ index.asp?mod=_fullart\&idart=190. Buletin Tata Ruang Online. Edisi Juli Agustus 2009. Diakses 2 Juni 2014.

Bayu Arie Wibawa, RTBL Sebagai Alat Perancangan Kota "IDEAL" Untuk Pengaturan Bangunan dan Lingkungannya, http://www.inkindojateng.web.id/?p=792 diakses 26 Desember 2014.

Galih-Rentek, Dokumen RTBL Untuk Mendukung Perwujudan Permukiman Layak Huni dan Berkelanjutan, http://ciptakarya.pu.go.id/water/ 
post.php?q=3905-Dokumen-RTBL-Untuk-Mendukung.html diakses 14 Februari 2015.

Lubis, Joessair. Mewujudkan Pembangunan Kota Pesisir di Indonesia. http://penataanruang.pu.go.id/bulletin/index.asp?mod=_fullart\&idart=31 1. Buletin Tata Ruang Online. Edisi Juli - Agustus 2011. Diakses 16 Februari 2015. 